\title{
THE INFLUENCE OF FIRMS WITH EXCESS FREE CASH FLOW AND LOW GROWTH PERSPECTIVE TOWARDS EARNING MANAGEMENT
}

\author{
Marika Suma Raya Sembiring \\ Fakultas Bisnis Universitas Presiden \\ marikasumaraya@president.ac.id \\ Kathleen Kusuma Nugroho \\ Fakultas Bisnis Universitas Presiden \\ louis.kathleen.lk@gmail.com
}

\begin{abstract}
This research aims to investigate whether firms with excess of free cash flow and low growth perspective are tend to engage in earnings management with several control variables included. We predict the relationship between each variable using multiple regressions model. The data sample used is manufacturing companies listed in IDX from the year of 2012 to 201. The result of this research presents that there is no significant relationship between excess of free cash flow and earnings management. The reasons behind this result might be a difference in type of agency problem, in dividend policy, and in organization behavior widespread across the countries. However, we found a significant relationship between control variables to the dependent variable by means of discretionary accruals, which are firm size, IFRS implementation and audit quality towards earnings management.
\end{abstract}

Keywords: Agency Problem, Earnings management, Excess Free Cash Flow, Dividend Payment.

\section{Background}

According to Statement of Financial Accounting Concepts (SFAC) No. 1, earnings information is fundamental and important information for creditors, investors, and other users of financial statements which aims to evaluate the performance of management, estimate "earning power" of a firm, forecast future earnings, and asses the investing and borrowing risk. In regards with this issue, the primary accounting standard-setting bodies - the International Accounting Standards Boards (IASB) and the Financial Accounting Standards Boards (FASB) requires that an entity should present its financial statements using the accrual basis of accounting, except for cash flow information. The accrual basis of accounting is an accounting system trying to combine current cash inflows or outflows with the future expected cash inflows or outflows to provide a clearer image of a company's current financial condition. The research of Dechow, Richardson \& Tuna (2003) indicates that accruals significantly influence the earnings quality.

Despite that the standard setters require the implementation of accrual basis in a firm, at the same time it allows the management to have some flexibility in accounting discretion over the recognition of accruals. This discretion may lead the management to opportunistically manipulate earnings (Dechow, 1994) and to its expected level that potentially could mislead the users of financial statements. This earnings manipulation latter known as earnings management. Earnings management refers to apply accounting method under generally accepted accounting principles (GAAP) intentionally in order to have discretion over discretionary account to achieved a desired earnings (Bhundia, 2012). The extreme action of earnings management may lead to a financial fraudulent or even a 
bankruptcy of a firm. For example, the scandal of Satyam Computer Service (IND), which is also called the Enron of India leads to a huge lost for its investor as much as $\$ 2.2$ billion as Satyam's shares shrunk responding to the company's former chairman's confession that he had manipulated the company's earnings nearly \$1.1 billion (Balachandran, 2015).

There are many factors which might influence the management to have discretion over accruals account in order to achieve desired earnings, one of them is agency problem between management and shareholders. Jensen \& Meckling (1976) describe the shareholders of firm as the principal, and the management as the agent. The agent acts as the representative of the principals within the firm and is responsible to them by disclosing the performance of a firm during one accounting period in the form of financial statements. However, if both management and principal have self interest in maximizing their own wealth, thus it is quite reasonable to believe that an agent does not always act on behalf of the principal and in the best interest of the principal. Instead, an agent might act to maximize their interest at the expensed of the principals.

Companies with high level of free cash flow have bigger chance to engage in earnings management. Previous researches indicate that companies with high level of free cash flow and low investment opportunity are more often facing the major agency problem (Chung, Firth \& Kim, 2005). According to Jensen, dividend distribution to shareholders creates a conflict between management and shareholders since it reduces the available resource of fund which is in the control of managers. As well as Jensen, lots of financial analysts raise the same argument that the available resource in cash should be invested in fixed assets only (cash used in investing activities), but should also be distributed as dividend to shareholders. This reduction of available resource might impact to the power of managers within the firm, and thus makes managers do monitoring of the capital market in order to obtain new fund.

In order for the resources not leaving the firm, in the absence of shareholders' supervision, manager may use this opportunity to maximize their wealth by investing the available free cash flow in unprofitable projects, misuse the funds over investments (Jensen, 1986). Meanwhile, it is by no means that the shareholders would like to forgo dividend but do not require a higher return on this investment. Yet, keeping a promise to give higher return is not that easy and simple, therefore, earnings management plays role as a tool to camouflage the impact of negative investment to soothe the shareholders and preserve the managers' position at the same time (Cardoso, Martinez, \& Teixeira, 2014).

Equally important, there will be so many factors which might influence earnings management, thus the researcher tries to consider other factors such as shareholder's concentration, the size of the firm, leverage, audit quality, loss, and IFRS implementation to support this research. The result from previous studies done by Chung, Firth, Kim (2005), Bukit and Iskandar (2009), Bundhia (2012), and Cardoso et al (2014) support the theory of Jensen (1986) that it is found a positive relationship and significant influence between excess of free cash flow to earnings managements which is measured by discretionary accruals in firms with excess of free cash flow and low growth firms. Thus, it can be concluded that the theory of free cash flow by Jensen (1986) might still be relevant to current condition.

However, this study does not aim to proof the relevancy theory of Jensen to current condition, instead this study aims to give another perspective regarding the relationship between free cash flow and earnings management according to free cash flow theory by Jensen especially in Indonesia where there still few researches discussing about this topic. 
Marika Suma Raya Sembiring

Kathleen Kusuma Nugroho
Jurnal Manajemen Bisnis Indonesia

Vol. 3, Nomor 3, Juni 2016

\section{Literature Review and Hypothesis Development}

\section{Literature Review}

\section{Earnings Management}

According to Healy and Whalen (1999) in Bukit and Iskandar (2009), companies facing major agency problems are very common to engage in earnings manipulation. It may involve manipulation on accounting documents, intentional omission or misuse of accounting principles. It gets severe when earnings manipulation leads to earnings fraud which is a fraudulent in financial reporting by presenting misleading information in financial statements to deceive the users (MIA, 2002). "Earnings management occurs when managers use judgment in financial reporting and in structuring transactions to alter financial reports to either mislead some stakeholders about the underlying economic performance of the company or to influence contractual outcomes that depend on reported accounting numbers" (Healy \& Wahlen, 1999; p.6).

According to Bukit \& Iskandar (2009), direct rewards in the form of compensation and bonus or indirect rewards by offering a future promotion, a prestigious position or job, and job security are often motivating managers to gain personal benefits. Mostly, these rewards are given based on company's earnings achievement. If it is, then managers will be likely to perform in order to fulfill their self interest as to gain personal benefits offered by presenting a good performance of the company to shareholders through earnings management. The ability of managers to manage accruals in order to affect the reported earnings as well as affect the managers' compensation may lead to major agency problem.

As a result of earnings management, the financial reporting does not faithfully present and reflect the real economic conditions of the company. In the other side, the users of financial statements use the financial information to make decisions which are reflected in the share price. The decisions made based on the "managed" accounting information may cause the shares undervalued.

There have been many researches studied about earnings management and thus the proxies of earnings management are developing. The researchers use discretionary accrual proxy such as Healy (1985) uses total accruals, DeAngelo (1986) uses changes in total accruals, Jones (1991) uses residual from regression of total accruals on changing in sales and property, plant and equipment, and Modified Jones Model from Dechow et al.(1996) uses residual from regression of total accruals on change in sales and property, plant and equipment, when revenue is adjusted for change in receivables in the event period.

In this research, researcher applies The Modified Jones Model by Dechow (1996) to detect earnings management practice since this model includes the changes in total receivables which believed to be potentially manipulated. Therefore, this model might be the most effective one to detect earnings management since there are many studies which had been used this model already.

\section{Hyphotesis Development}

\section{The Relationship between Free Cash Flow and Earning Management}

Jensen (1986), in Bhundia (2012), introduced the theory of free cash flow and defined it as the cash from operating activities after deducting any payment in cash in order to have excess cash to be invested in project with positive net present (NPV) value when it is discounted with weighted averaged cost of capital (WACC). According to Len and Poulsen 
(1989) in Cardoso et al (2014) free cash flow is operating income before depreciation expense after tax, interest expense and preferred and common stock dividend payment. For Dechow and Ge (2006) free cash flow is the cash flows from operating activities plus the cash flows from the investment activities.

According to Bundhia (2012) and Jensen (1986), allocating free cash flow is the most common agency problem faced by the company. Agency problem is raised when free cash flow available in the company is not used for the best interest of shareholders. Instead, in the absence of direct monitoring from the shareholders the managers choose to invest in unprofitable projects for their self interest at the expense of shareholders. The negative impact of this unprofitable investment may lower the growth of the company (Bhundia, 2012) and lead to lower stock price which might adversely affect the company's financial position and possibly cause the managers to be replaced (Nikhili, Amar, Chtioui, \& Lakhal, 2016).

The asymmetry gap between the management and shareholder may allow the managers to cover the negative impact of unprofitable investment by presenting as minimal disclosure as possible regarding the activities or manipulating the accounting number (Bukit $\&$ Iskandar, 2009). As a result, investors do not have any access of information whether the investment is giving benefit or loss to their wealth (Chung et al, 2005).

Nekhili et al (2016) finds out that availability of free cash flow allows manager to have the opportunity to manage earnings. Cardoso et al (2014) and Bundhia's (2012) studies result the same findings that firms with excess of free cash flow and low growth perspective tend to engage in earnings management. However, Rusmin et al (2014) documented a positive relationship between free cash flow and earnings management, however this relationship is partially applicable in Singapore, yet it is not applicable in Indonesia. Selahudin et al (2016) recently also conducted a research to seek relationship between free cash flow and earnings management in Thailand and Malaysia, and found no significant relationship between earnings management and free cash flow. Taking all of these into accounts, these arguments lead to our hypothesis:

H1: There is a significant relationship between firms with excess of free cash flow and low growth perspective towards discretionary accruals by means of earnings management.

\section{Control Variables of Earnings Management.}

\section{Leverage}

Debt covenant hypothesis in Positive Accounting Theory presented that the higher the debt to equity ratio of a firm, the closer it may violate the debt covenant, and thus managers are motivated to select accounting method which may allow them to drag reported income from next period to the current period. This is because higher net earnings will reduce the probability of a firm to breach debt covenant since if the firms are violating the debt agreement, they might be fined some penalties by the debtors. Lambert (2001) in Cardoso et al (2014) suggests that to avoid breaching a debt covenant, managers may exercise their influence over financial reporting. Beatty and Weber (2003) in Bhundia (2012) suggests that leveraged firms engage in earnings management to avoid debt covenant default.

\section{Firm Size}

Relationship between firm size and earnings management suggested that larger firms are usually under pressure of capital market monitoring and thus show more tendency towards earnings management (Lusi \& Swastika, 2013). Consistently, Barton and Simko 
(2002) in Cardoso et al (2014) indicate that larger firms encounter higher pressure on meeting or beating the analyst's expectations. Large firms usually have higher current assets which turn to give discretion to manage earnings. Watts \& Zimmerman (1986) suggested that firm size might lead to higher political cost. Larger firms usually face higher political costs and therefore are motivated to apply accounting discretion in order to reduce unwanted political views. Government also requires large company to do more corporate social responsibilities. Hence, larger company has probability to lower its profit in order to evade the control from government and reduce political cost. It concludes that the larger the firms are, the higher the political costs and the scale cost.

\section{Audit Quality}

The existence of asymmetry gap between principal and management in agency problem creates a demand for external audit. The responsible of external auditors are to verify the conformity of financial statements to GAAP and whether the information disclosed is faithfully reflecting the company's economic true condition (Lin \& Hwang, 2010). The audit opinion given by the external auditors adds credibility to the company's financial statements. In addition, auditing standards require the external auditors to discus and communicate with audit committee not only the acceptability of accounting principles applied but also the quality. Therefore, it is expected that audit quality will reduce the risk of material misstatement or omissions in financial statements as well as to reduce earnings management.

\section{IFRS}

Accounting theory argues in order to reduce the information asymmetry; firm should disclose the financial statements which reflect the firm's economic true condition in a timely basis (S.Soderstrom \& Sun, 2007). Before the implementation of IFRS is adopted widespread across the countries, companies followed a variety GAAP of every country. The implementing of IFRS gives a shared set of standard which can help to easily having a big picture about the financial performance and condition of companies across different countries. This may enhance the transparency of financial reporting disclosed and improve its quality so that the reliable accounting number may be presented to users (Jeanjean \& Stolowy, 2008). The higher quality of financial reporting may lower the possibility of earnings management.

\section{Shareholder's Concentration}

Managerial ownership can be defined as the share owned by stakeholders who are actively taking roles in decision making. Management ownership is aiming to give reward to the management for their dedication and performance. It is believed that management ownership may reduce agency costs as managers with relatively large share are more in line with shareholder's motivation and interests, and thus may reduce earnings management (Chung, Firth, \& Kim, 2005).

\section{Absolute Total Accrual}

According to Becker et al (1998) in Rusmin et al (2014) the absolute total accrual is included to be the control variable in this research in order to control a firm's "accrualgenerating potential". The theory developed is firms with higher total accrual are likely to 
engage in earnings management (Krishnan, 2003). Thus, we would expect a positive relationship between absolute total accruals and discretionary accruals.

\section{Cash Flow}

Cash flow is the net amount of cash and cash-equivalents which flow into and out of a business. Amount of positive cash flow indicates that a firm's liquid assets is increasing which enables it to pay for debts, invest this resources into new project or business, and pay dividends. According to Bukit and Iskandar (2012), a higher level of cash flow might motivate managers to use discretionary accruals to smooth earnings in order to meet analyst's projections and increasing stock price. Chung et al (2005) also argues the same thing with Bukit and Iskandar (2012), that these authors expect a positive relationship between cash flow and discretionary accruals by means of earnings management.

\section{Research Methodology}

\section{Sample}

The sample of this research is manufacturing companies listed in Indonesian Stock exchange in the period year from 2012 to 2015. The criteria applied are in these following:

1. Companies which are continually listed from 2012 to 2015.

2. Companies which continually published a complete set of financial statements from 2012 to 2015.

3. Companies which provide the necessary information used in data processing (calculation of each variable measurement).

4. Companies whose accounting period ends in December 31 from 2012 to 2015.

\section{Operational Definition and Variable Measurement}

\section{Dependent Variable: Earning Management}

The proxy used to measure earnings management is discretionary accruals (DA). The model applied is Modified Jones Model by Dechow (1996) to separate non-discretionary accrual (NDA) components from discretionary accruals component (NDA) in the total accrual (TA). According to Dechow, Sloan and Sweeney (1996), Modified Jones Model provides the most powerful test of earnings management. In Cornett et al (2008), Modified Jones Model defined as follow:

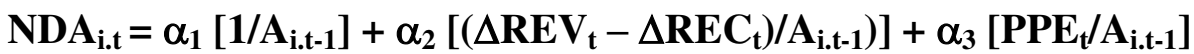

$$
\begin{aligned}
& \text { Where: } \\
& \text { NDA = non-discretionary accrual items at year } \mathrm{t} \\
& \triangle \mathrm{REV}_{\mathrm{t}}=\text { revenues in year } \mathrm{t} \text { less revenue in year }(\mathrm{t}-1) \\
& \triangle \mathrm{REC}_{\mathrm{t}}=\text { net receivables in year } \mathrm{t} \text { less net receivables in year }(\mathrm{t}-1) \\
& \mathrm{PPE}_{\mathrm{t}} \quad=\text { gross property, plant and equipment in year } \mathrm{t} \\
& \mathrm{A}_{\mathrm{i} . \mathrm{t}-1}=\text { total assets of firm } \mathrm{i} \text { at year }(\mathrm{t}-1) \\
& \alpha_{1}, \alpha_{2}, \alpha_{3}=\text { firm-specific parameters and calculated by following equation: } \\
& \mathbf{T A}_{\mathrm{t}} / \mathbf{A}_{\mathrm{it}-1}=\alpha_{1}\left[1 / \mathbf{A}_{\mathrm{i} . \mathrm{t}-1}\right]+\alpha_{2}\left[\Delta \mathbf{R E V} \mathrm{V}_{\mathrm{t}} / \mathbf{A}_{\mathrm{i} . \mathrm{t}-1}\right]+\alpha_{3}\left[\mathbf{P P E}_{\mathrm{t}} / \mathbf{A}_{\mathrm{i}, \mathrm{t}-1}\right]+\mathrm{e}
\end{aligned}
$$

TA is a proxy for total accrual items at year t. Total accrual items is calculated by following equation:

$\mathbf{T A}_{\text {it }}=\mathbf{N I}-\mathbf{C F O}$ 
In addition, discretionary accruals $\left(\mathrm{DA}_{\mathrm{it}}\right)$ are calculated by the difference between total accruals $\left(\mathrm{TA}_{\mathrm{it}}\right)$ and non-discretionary accruals $\left(\mathrm{NDA}_{\mathrm{it}}\right)$ as following:

$$
\begin{aligned}
& \mathbf{D A}_{i t}=\mathbf{T} \mathbf{A}_{i t} / \mathbf{A}_{i t-1}-\mathbf{N D A}_{i t}
\end{aligned}
$$

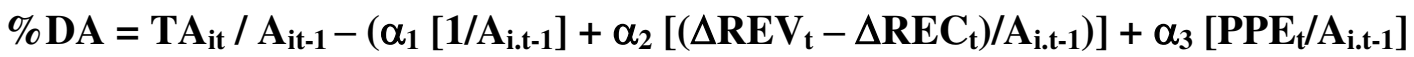

\section{Independent Variable: EFCF}

According to Cardoso et al (2014), EFCF is the variable to measure whether there is a relationship between FCF in firms with low growth perspective and earnings management by means of discretionary accruals. It is a dummy variable consists of two other dummy variables. The first of these compares whether the value of FCF calculated of a firm is greater than the median FCF value for all firms in a specific year. If the FCF value is greater than the median, the dummy variable assumes value of 1 , and 0 otherwise.

The second of these dummy variables is the price-to-book ratio. The logic behind the use of this ratio is that the market recognizes the firms with greater growth perspectives, by bidding up the stock price above the book value. Thus, to capture the firms with low growth perspective in a certain year, we calculated the price-to-book ratio of all firms, and assume value of 1 for the $\mathrm{P} / \mathrm{B}$ ratio which is below the median and 0 otherwise. The variable EFCF is obtained by multiplying the dummy variable FCF and $\mathrm{P} / \mathrm{B}$ ratio, with value 1 when there is excess FCF in a firm with low growth perspectives and 0 otherwise.

In order to clarify, there is a different between excess cash and excess free cash flow. Excess cash shows how much the cash from operating activity after combined or deducted with cash from investing and financing activities. The excess of free cash flow shows how much firm cash in hand after deducted with several expenditures such as dividend and interest.

As in Bundhia (2012), Len and Pulson model (1989) is applied in order to measure free cash flows. According to this model FCF is measured as operating income before depreciation deducted by total of taxes, interest cost and dividend from operating income, standardized by dividing it to assets.

$$
\begin{aligned}
& \mathrm{FCF}_{\text {i.t }}=\left(\mathrm{INC}_{\text {i.t }}-\mathrm{TAX}_{\text {i.t }}-\mathrm{INTEP}_{\mathrm{i} . \mathrm{t}}-\mathrm{PSDIV}_{\text {i.t }}-\mathrm{CSDIV}_{\text {i.t. }}\right) / \mathrm{TA}_{\text {i.t- } 1} \\
& \mathrm{P} / \mathrm{B} \text { ratio }=\text { Market price } /(\mathrm{BV} / \text { share }) \\
& \mathrm{BV}=\mathrm{TA}_{\mathrm{t}}-\mathrm{TL}_{\mathrm{t}} \\
& \mathrm{BV} / \text { Share }=\left(\mathrm{TA}_{\mathrm{t}}-\mathrm{TL}_{\mathrm{t}}\right) / \text { Outstanding shares } \mathrm{t}_{\mathrm{t}} \\
& \text { Where, } \\
& \text { FCF } \quad=\text { free cash flow firm of year } \mathrm{t} \\
& \mathrm{INC}_{\mathrm{i} . \mathrm{t}} \quad=\text { operating income after depreciation of firm } \mathrm{i} \text { at year } \mathrm{t} \\
& \text { TAX }_{\text {i.t }} \quad=\text { total taxes of firm } \mathrm{i} \text { at year } \mathrm{t} \\
& \text { INTEP }_{\text {i.t }} \quad=\text { interest expense of firm } \mathrm{i} \text { at year } \mathrm{t} \\
& \text { PSDIV }_{i . t} \quad=\text { preferred stock holders dividends of firm } \mathrm{i} \text { in year } \mathrm{t} \\
& \text { CSDIV }_{i . t} \quad=\text { common stock holders dividends of firm } \mathrm{i} \text { in year } \mathrm{t} \\
& \mathrm{TA}_{\mathrm{i} . \mathrm{t}-1} \quad=\text { total asset of firm } \mathrm{i} \text { in year }(\mathrm{t}-1) \\
& \mathrm{P} / \mathrm{B} \text { ratio } \quad=\text { price-to-book value of firm } \mathrm{i} \text { at year } \mathrm{t} \\
& \mathrm{BV} \quad=\text { book value of firm } \mathrm{i} \text { at year } \mathrm{t} \\
& \mathrm{TA}_{\mathrm{t}} \quad=\text { total asset of firm } \mathrm{i} \text { in year } \mathrm{t} \\
& \mathrm{TL}_{\mathrm{t}} \quad=\text { total liabilities of firm } \mathrm{i} \text { in year } \mathrm{t}
\end{aligned}
$$




\section{Control Variable}

1. Leverage (LEV)

Debt covenant is measured by financial leveraged which Cardoso (2014) defined as total debt divided by total assets in previous year (book leverage).

2. Firm Size (SIZE)

Firm size is one of the most common variables used in earnings management research (Francis, Nanda, \& Olsson, 2008). Firm size is measured by natural logarithm of total assets in year $\mathrm{t}$.

3. Cash Flow (CF)

Difference between the firm's cash flow and the annual median of the sample divided by total assets in the previous year.

4. Shareholder Concentration (ESC)

Dummy variable for shareholding concentration, with value 1 when the percentage of common shares held by the largest shareholder is above the annual median of the sample and 0 otherwise.

5. Absolute Total Accruals (AB_TACC)

Absolute value of total accruals divided by total assets of previous year.

6. IFRS

Dummy variables that assume 1 for observation in 2012, 2 in 2013, 3 in 2014, and 4 in 2015 due to requirement to use IFRS in those years.

7. IFRS*EFCF

Dummy variable that seeks to capture the interaction of the influence of adopting IFRS and the excess of free cash flow.

8. Audit Quality (AQ)

Dummy variable that assume value of 1 when a firm is audited by BIG Four Accounting Public (Pricewaterhouse Coopers, Delloitte, KPMG, Ernst \& Young), and 0 otherwise.

\section{Research Model}

According to operational proxy of independent and dependent variables that have been explained above, this study develops the research model as follow,

$$
\begin{aligned}
& \mathbf{D A}_{\mathrm{i} . \mathrm{t}}=\beta_{\mathbf{0}}+\beta_{1} \mathbf{E F C F}_{\mathrm{i}, \mathrm{t}}+\beta_{2} \mathrm{ESC}_{\mathrm{i}, \mathrm{t}}+\beta_{3} \mathbf{S I Z E}_{\mathrm{i.t}}+\beta_{4} \mathbf{L E V i}_{\mathrm{t} t}+\beta_{5} \mathbf{C F}_{\mathrm{i.t}}+ \\
& \beta_{6} \mathbf{A B}_{-} \mathbf{T A C C}+\beta_{7} \text { IFRS }_{\mathrm{i}, \mathrm{t}}+\beta_{8} \text { IFRS }^{*} \mathbf{E F C F}_{\mathbf{i}, \mathrm{t}}+\beta_{9} \mathbf{A Q}+\mathbf{e}
\end{aligned}
$$

\section{Result And Discussion}

There are 95 companies that meet the sampling criteria. However, in order for data to be normally distributed, we tried to eliminate the outliers. Outliers are data whose values is higher than maximum value and lesser than minimum value calculated. The maximum value is calculated by using this formula: average $+(3 \mathrm{x}$ standard deviation $)$; while the minimum value is calculated by using this formula: average - $(3 \mathrm{x}$ standard deviation $)$. After the outliers are omitted, the final samples of this research are 40 


\begin{tabular}{|l|l|}
\hline Total Population & 144 \\
\hline Eliminated due to year of IPO & 17 \\
\hline $\begin{array}{l}\text { Eliminated due to unavailability of } \\
\text { Financial Statements }(2012-2015)\end{array}$ & 2 \\
\hline $\begin{array}{l}\text { Eliminated due to difference of } \\
\text { accounting period year end }\end{array}$ & 4 \\
\hline $\begin{array}{l}\text { Eliminated due to unavailability of } \\
\text { data related to variable measurement }\end{array}$ & 26 \\
\hline Outliers & 55 \\
\hline Total Final Sample & 40 \\
\hline
\end{tabular}

\section{Table 1. Sample Detail}

Before testing the relationship between variables, we first performed a descriptive statistical analysis of each variable. The results are presented in the following table.

\begin{tabular}{|c|c|c|c|c|c|c|c|c|}
\hline Variable & $\mathbf{N}$ & Mean & Median & Max & Min & Std.Dev & $\begin{array}{c}\text { Skewnes } \\
\text { s }\end{array}$ & Kurtosis \\
\hline DA & $\begin{array}{c}16 \\
0\end{array}$ & 3.138479 & $\begin{array}{c}2.31433 \\
6\end{array}$ & $\begin{array}{c}13.6733 \\
0\end{array}$ & $\begin{array}{c}- \\
13.0006 \\
7\end{array}$ & 5.577197 & $\begin{array}{c}- \\
0.376139\end{array}$ & 3.017618 \\
\hline EFCF & $\begin{array}{c}16 \\
0\end{array}$ & 0.187500 & 0.00000 & $\begin{array}{c}1.00000 \\
0\end{array}$ & $\begin{array}{c}0.00000 \\
0\end{array}$ & 0.391538 & 1.601282 & 3.564103 \\
\hline ESC & $\begin{array}{c}16 \\
0\end{array}$ & 0.506250 & 1.00000 & $\begin{array}{c}1.00000 \\
0\end{array}$ & $\begin{array}{c}0.00000 \\
0\end{array}$ & 0.501531 & $\begin{array}{c}- \\
0.025002\end{array}$ & 1.000625 \\
\hline SIZE & $\begin{array}{c}16 \\
0\end{array}$ & 28.71645 & $\begin{array}{c}28.4361 \\
1\end{array}$ & $\begin{array}{c}32.2059 \\
8\end{array}$ & $\begin{array}{c}25.6348 \\
1\end{array}$ & 1.510211 & 0.271647 & 2.170533 \\
\hline LEV & $\begin{array}{c}16 \\
0\end{array}$ & 0.425582 & $\begin{array}{c}0.39731 \\
5\end{array}$ & $\begin{array}{c}2.48821 \\
3\end{array}$ & $\begin{array}{c}0.00108 \\
5\end{array}$ & 0.385868 & 2.963935 & 15.37859 \\
\hline $\mathbf{C F}$ & $\begin{array}{c}16 \\
0\end{array}$ & 0.006686 & $\begin{array}{c}- \\
0.00026 \\
4\end{array}$ & $\begin{array}{c}0.39239 \\
8\end{array}$ & $\begin{array}{c}- \\
0.16455 \\
0\end{array}$ & 0.055127 & 2.491978 & 18.88457 \\
\hline AB_TACC & $\begin{array}{c}16 \\
0\end{array}$ & 0.062795 & $\begin{array}{c}0.04790 \\
7\end{array}$ & $\begin{array}{c}0.44930 \\
4\end{array}$ & $\begin{array}{c}0.00010 \\
7\end{array}$ & 0.057700 & $\begin{array}{c}2.798867 \\
4\end{array}$ & 15.89083 \\
\hline IFRS & $\begin{array}{c}16 \\
0\end{array}$ & 3.500000 & $\begin{array}{c}3.50000 \\
0\end{array}$ & $\begin{array}{c}5.00000 \\
0\end{array}$ & $\begin{array}{c}2.00000 \\
0\end{array}$ & 1.121544 & 0.000000 & 1.640000 \\
\hline $\begin{array}{l}\text { IFRS*EFC } \\
\text { F }\end{array}$ & $\begin{array}{c}16 \\
0\end{array}$ & 0.687500 & $\begin{array}{c}0.00000 \\
0\end{array}$ & $\begin{array}{c}5.00000 \\
0\end{array}$ & $\begin{array}{c}0.00000 \\
0\end{array}$ & 1.513825 & 1.946783 & 5.209739 \\
\hline AQ & $\begin{array}{c}16 \\
0\end{array}$ & 0.500000 & $\begin{array}{c}0.50000 \\
0\end{array}$ & $\begin{array}{c}1.00000 \\
0\end{array}$ & $\begin{array}{c}0.00000 \\
0\end{array}$ & 0.501570 & 0.000000 & 1.000000 \\
\hline \multicolumn{5}{|c|}{ Dummy Variable } & \multicolumn{2}{|c|}{ Dummy $=1$} & \multicolumn{2}{|c|}{ Dummy $=0$} \\
\hline \multicolumn{5}{|c|}{ EFCF } & \multicolumn{2}{|c|}{$18.75 \%$} & \multicolumn{2}{|c|}{$81.25 \%$} \\
\hline \multicolumn{5}{|c|}{ ESC } & \multirow{2}{*}{\multicolumn{2}{|c|}{$\begin{array}{c}56 \% \\
55.56 \%\end{array}$}} & \multicolumn{2}{|c|}{$44 \%$} \\
\hline \multicolumn{5}{|c|}{$\mathbf{A Q}$} & & & \multicolumn{2}{|c|}{$44.44 \%$} \\
\hline
\end{tabular}

Table 2. Statistic Descriptive

The mean of discretionary accrual in order to measure earnings management is 3.13 with the maximum value is 13.67 and minimum value is -13.67 . The closer the value to 0 indicates that the company is doing lower accruals management or we can say that the 
intention to engage in earnings management is lower. The company which has the maximum value of 13.67 is PT. Tifico Fiber Indonesia Tbk (TFCO), while the company which has the minimum value -13.00 is PT Kalbe Farma Tbk (KLBF). The descriptive data shown above is obtained after some outliers are omitted. Before the outliers are omitted, the highest value of discretionary accrual is 469.51 which owned by PT PT. Citra Tubindo Tbk (CTBN).

EFCF is the variable used to capture whether there is a relationship between free cash flow in the firms with low growth perspective with earnings management. Value of 1 , $18.75 \%$ of total samples, indicates the firm with excess free cash flow and low growth perspective. Meanwhile, the value of $0,81.25 \%$ of total samples, indicates the firms with less free cash flow and high growth perspective. According to this descriptive table, it is informed that mostly of our samples are firms with lower free cash flow and high growth perspective.

ESC is the variable to capture the relationship between shares ownership and earnings management. The proportion dummy variable with value 1 indicates that $56 \%$ of firms have greater ownership concentration than the annual median of the sample, and value of 0 indicates that $44 \%$ of firms have lower ownership concentration.

The maximum value of SIZE is 32.20 which belong to PT Indah Kiat Pulp \& Paper Tbk (INKP) with total assets in $2015 \mathrm{Rp} 97,024,509,420$. Meanwhile the minimum value is 25.63 which belong to PT Intanwijaya International Tbk (INCI) with total assets in $2012 \mathrm{Rp}$ $132,278,839,080$.

Leverage is to measure the proportion of debt used to fund the company. The more debt financing a company uses, the higher the financial leverage is. High debt level may lead company to breach debt covenant, credit downgrades, or even bankruptcy. The maximum value of leverage is 2.5 (250\%) belongs to PT Jakarta Kyoei Steel Works Tbk (JKSW) with total debt approximately 650 billion rupiah while the total asset is only approximately 287 billion rupiah in 2014. In the other hand, the minimum value is $0.001085(0.11 \%)$ which belongs to PT KMI Wire and Cable Tbk (KBLI) with total debt approximately 1.2 billion rupiah and total assets 1.1 trillion rupiah. Compare to the mean of leverage of all samples, $42.5 \%$, PT. Jakarta Kyoei Steel Works Tbk might be considered to have very high financial risk.

$\mathrm{CF}$ is the variable to measure the level of high cash flow by subtracting the cash flow of firm and the annual median of the sample, divided by total assets year $\mathrm{t}-1$. The maximum value of cash flow is 0.39 belongs to PT Pan Brothers (PBRX) in 2012 and the lowest is -0.16 belongs to PBRX as well in 2015. The higher level of cash flow might tend to use discretionary accruals to smooth income in order to meet analyst's projection.

Absolute Accrual (AB_TACC) indicates the total value of accruals within net income. The maximum value of total accrual is 0.45 which might indicate that $45 \%$ of net income is containing accruals. PT Panasia Indo Resources Tbk in 2013 owns the maximum value of total accrual. Accruals itself is the amount you are yet to pay or receive. Meanwhile, the minimum value of total accrual is 0.000107 which indicates that there is very small percentage of accrual. The minimum value of total accrual owned by PT Nipress Tbk in 2012. This is also marked by the lower level of leverage which is only $5 \%$, and value of discretionary accruals is -10.97 .

IFRS and IFRS*EFCF are the variable used to see whether the implementation of IFRS in accounting discretions is more being used every year. The enhancement of accounting information is believed to be aligned with the implementation of IFRS.

AQ refers to audit quality which aims to capture whether there is influence to earnings management between companies audited by big four accounting firms and non big four accounting firms. 55.56\% of total samples is audited by big four accounting firms, and the remaining samples are audited by non big four accounting firms. It is wished that the audit 
quality will reduce the earnings management intention since it is believed that better audit quality report is resulted from big four accounting firms.

\section{The Influence of Free Cash Flow to Earnings Management}

The result of regression shows the Prob t-test of our independent variable, which is free cash flow (EFCF) 0.3404. The value of Prob t-test indicates whether the independent variable significantly influence the dependent variable. It gives significant influence if the value of Prob two-tailed is lower than alpha. In here, the Prob two-tailed value of EFCF is 0.3404 which is higher than $0.05(\alpha=5 \%)$. This means that the independent variable, EFCF, does not have any significant influence to earnings management by means of discretionary accruals.

\begin{tabular}{|c|c|c|c|c|}
\hline Variable & $\begin{array}{r}\text { Coeffici } \\
\text { ent }\end{array}$ & Std. Error & t-Statistic & Prob. \\
\hline EFCF & $\begin{array}{r}3.51489 \\
9\end{array}$ & 3.675171 & 0.956391 & 0.3404 \\
\hline ESC & $\begin{array}{r}- \\
0.01368 \\
0\end{array}$ & 0.925292 & -0.014785 & 0.9882 \\
\hline$* *$ SIZE & $\begin{array}{r}0.68771 \\
6\end{array}$ & 0.325617 & 2.112041 & 0.0363 \\
\hline LEV & $\begin{array}{r}0.57768 \\
3\end{array}$ & 1.174836 & 0.491714 & 0.6236 \\
\hline $\mathrm{CF}$ & $\begin{array}{r}- \\
10.1909 \\
0\end{array}$ & 7.618932 & -1.337576 & 0.1831 \\
\hline AB_TACC & $\begin{array}{r}4.29891 \\
5\end{array}$ & 7.327211 & 0.586706 & 0.5583 \\
\hline$* * *$ IFRS & $\begin{array}{r}1.81163 \\
2\end{array}$ & 0.413281 & 4.383534 & 0.0000 \\
\hline IFRS_X_EFCF & $\begin{array}{r}- \\
0.97963 \\
9\end{array}$ & 0.970371 & -1.009551 & 0.3143 \\
\hline *AQ & $\begin{array}{r}- \\
1.78953 \\
0\end{array}$ & 0.992447 & -1.803149 & 0.0734 \\
\hline $\mathbf{C}$ & $\begin{array}{r}- \\
22.4825 \\
0\end{array}$ & 9.213022 & -2.440296 & 0.0158 \\
\hline R-squared & $\begin{array}{r}0.17097 \\
9\end{array}$ & \multicolumn{2}{|c|}{$\begin{array}{l}\text { Mean dependent } \\
\text { var }\end{array}$} & $\begin{array}{r}3.1384 \\
79\end{array}$ \\
\hline $\begin{array}{l}\text { Adjusted R- } \\
\text { squared }\end{array}$ & $\begin{array}{r}0.12123 \\
8\end{array}$ & \multicolumn{2}{|c|}{ S.D. dependent var } & $\begin{array}{r}5.5771 \\
97\end{array}$ \\
\hline S.E. of regression & $\begin{array}{r}5.22819 \\
2\end{array}$ & \multicolumn{2}{|c|}{$\begin{array}{l}\text { Akaike info } \\
\text { criterion }\end{array}$} & $\begin{array}{r}6.2064 \\
70\end{array}$ \\
\hline $\begin{array}{l}\text { Sum squared } \\
\text { resid }\end{array}$ & $\begin{array}{r}4100.09 \\
9\end{array}$ & \multicolumn{2}{|c|}{ Schwarz criterion } & $\begin{array}{r}6.3986 \\
68\end{array}$ \\
\hline
\end{tabular}




\begin{tabular}{lrlr}
\hline Log likelihood & - & Hannan-Quinn & 6.2845 \\
& 486.517 & criter. & 15 \\
& 6 & & \\
F-statistic & 3.43737 & Durbin-Watson stat & 1.9410 \\
& 7 & & 46 \\
Prob(F-statistic) & 0.00070 & & \\
\hline
\end{tabular}

Table 3. Regression Result

The result of our finding is on the contrary with several previous researches. Cardoso et al (2014) and Bundhia's (2012) findings show that firm with high level of free cash flow and low growth perspective tends to engage in earnings management by means of discretionary accruals. Their findings show the positive relationship between free cash flow and earnings management. Meanwhile, the result of our finding also bears a positive relationship between free cash flow and earnings management. Which might indicate that there is possibility of firms with high free cash flow and low growth perspective in Indonesia to engage in earnings management? However excess of free cash flow itself does not significantly influence the discretionary accruals. Positive relationship shows that the firms with high free cash flow and low growth perspective have possibility to engage in earnings management. The positive coefficient explains when the coefficient increase by value of 1 , the discretionary accruals is also increase. Nevertheless, there is no significant influence between EFCF and DA eventhough positive relationship is shown. Bottom line, that EFCF does not significantly influence the discretionary accruals.

In order to support our finding, we refer to Rusmin et al's (2014) research which aims to investigate the same issues, whether firms with higher level of free cash flow and low growth perspective are related to earnings management. The study focuses on companies listed in Indonesian Stock Exchange, Bursa Malaysia, and Singapore Stock Exchange. The result of the study does support the hypothesis that firms with high free cash flow and low growth perspectives tend to manage their earnings. However, this relationship found only in firms listed in Bursa Malaysia, and partially in Singapore. Yet, the relationship is not valid for firms listed in Indonesia Stock Exchange. The result conducted by Rusmin et al (2014) supports the finding of this research that it is not found any significant influence between free cash flow and earnings management in Indonesia. Another research by Selahudin et al (2014) was also conducted to examine the relationship between earnings management and leverage, financial distress, and free cash flow in Malaysia and Thailand. The finding of the research is free cash flow does not significantly affect the earnings management in Malaysia as well as in Thailand.

Eversince a research to seek for relationship between free cash flow and earnings management is rarely done in Indonesia, therefore the possible explanation is that the agency problems rise in every country might be different, and another factor such as organisation culture and factors related country of origin may affect the manager's behaviour. As our research is closely related to agency problem where Jensen \& Meckling (1976) suggest that the conflict arises when both agent and principle seek to maximise their own wealth, thus it is reasonable if agent acts for their own interest at the expense of principal. Hence, in its free cash flow theory, Jensen (1986) in Cardoso et al (2014) said that dividend payment is one major conflict in agency problem. Instead of paying dividend to shareholders, the manager will try to invest the money in negative net present value in order to maintain their power over the available resources. Maintaining their power same as maintaining their position in a firm. Earnings management plays role to camouflage the impact of negative investment by 
having discretion over accrual to present smoother financial reports to shareholders in exchange of unpaid dividend.

Responding to this issue, Bae et al (2012) suggest that cultural aspects are suggested as possible reasons to explain the cross-country differences in dividend distribution policy. Another study conducted by Baker \& Powell (2012) regarding dividend policy in Indonesia, presents findings that managers view dividend distribution is one of the most important determinant for earnings stability and the level of current and future earnings. The managers also believe that dividend payment has significant influence on stock prices and thus the effect of dividends payment is also becomes the important determinant of a firm market value. The evidence shows that managers of Indonesia firms perceive that dividend policy affects the firm value. In addition, information asymmetry exist between management and shareholders is also believed to be other determinant for dividend policy since dividend payment may be perceived as a signal of future profitability of a firm (Breurer, Rieger, \& Soypak, 2014).

Compare to Jensen's theory regarding dividend distribution as one of major agency problem faced by firms with high free cash flow, from this research findings we can conclude that dividend distribution matters for the sake of the firm value and thus it might minimise the possibility of agency problem happens in firm with high free cash flow as predicted by Jensen in Cordoso et al (2014) and Bundhia (2012). In regards with this finding, the data of dividend payment extracted by the researcher shows a stable dividend payment from 2012 to 2015 of forty manufacturing companies in Indonesia in point of 50\%. The dividend payment data is presented in the appendix table 4.3.4.1. In addition, after we do a data processing to obtain the number of firms with high free cash flow and low growth perspective, we found that only $18.75 \%$ from total sample forty companies which marked as firms with high level of free cash flow and low growth perspective. The data can be seen in table 4.2.1 descriptive statistic in appendix. Thus, we might draw a conclusion that a firm with high free cash flow is also take account for dividend payment. At the same time, this might explain why there is no significant influence between free cash flow and earnings management since mostly dividend is distributed to shareholders.

Taking all of these into account, the hypothesis of this result is rejected that there is no significant relationship between firms with excess of free cash flow and low growth perspective towards discretionary accruals by means of earnings management.

\section{The Influence of Control Variables to Earnings Management}

There are three variables controls which found to be significantly influence earnings management. The first control variable is SIZE which positive and significant at $5 \%$. The positive relationship between SIZE and DA by means of earnings management indicates that the bigger size of a firm, the higher possibility of a firm to engage in earnings management. This finding is as predicted by Cardoso et al (2014) and Swastika (2013). Relationship between firm size and earnings management suggested that larger firms are usually under pressure of capital market monitoring and thus show more tendency towards earnings management (Lusi \& Swastika, 2013). Consistently, Barton and Simko (2002) in Cardoso et al (2014) indicate that larger firms encounter higher pressure on meeting or beating the analyst's expectations. Large firms usually have higher current assets which turn to give discretion to manage earnings. Hence, larger company has probability to lower its profit in order to evade the control from government and reduce political cost.

The variable of IFRS is also positive and significant at $1 \%$. Unlike the research conducted by Cordoso et al (2014) which expect a negative relationship between IFRS and earnings management, our research results a positive relationship which means that the 
implementation of IFRS in subsequent years do not significantly reduce earnings management. Thus a reasonable implementation is that since IFRS is implemented, manager has flexibility in accounting options to have discretion over accruals accounts. This result is in line with the arguments raised by Jeanjean \& Stolowy (2008) that there is evidence that accounting standards give only few and limited contribution in determining the quality of financial reporting. They said that the implementation of accounting standard involves reasonable judgment and the use of private or insider information, and as a result, IFRS may provide managers with substantial discretion. How far this discretion might be used depends on the firm's culture and characteristics (Jeanjean \& Stolowy, 2008).

Another variable found to be significant is audit quality (AQ). It is negative and significant at $10 \%$. It is in line with the finding from Lin \& Hwang (2010) who found significant and negative relationship between audit quality and earnings management. It's consistent with a theory when auditor provides better audit quality report, earnings management is less likely. This finding also supported by recent research done by Chee at al (2016) who found that audit quality significantly influences the earnings management in Malaysia.

The other variable such as shareholders concentration, leverage, total accrual, cash flow, and interaction between IFRS and free cash flow do not have any significant influence to earnings management. The shareholders concentration (ESC) bears negative relationship to earnings management, which means that the greater shares ownership a management has the lower possibility of earnings management. This finding is in line with Cardoso et al (2014).

Leverage also does not significantly influence the earnings management as Ardison et al (2012) research result that found no significant influence between leverage and earnings management. The possible explanation the higher leverage leads to higher financial risk of a firm. Higher financial risk leads to a higher chance of a firm to breach debt covenant, and thus earnings management plays a role in order for a firm to avoid breaching debt covenant. However, there is a moderator variable which is debt covenant which might be more related to leverage. Therefore, perhaps the relationship between leverage and earnings management is clearer when relationship between leverage and debt covenant is observed as well. In addition according to Ardison et al (2012), there is beneficial consequence of debt because the increased debt might reduce manager's discretionary spending, and in turn, reduce earnings management.

Total accrual also does not have any significant influence over discretionary accruals. However, it bears a positive relationship between total accruals and discretionary accruals, means that when total accruals increase by value of one, the possibility of earnings management is also higher as Chung et al (2005) and Bhundia (2012) predicted.

Cash flow as well as the other control variables, does not have any significant influence over earnings management. Our result shows that greater cash flow tend to reduce earnings management. A plausible explanation might be a firm with higher level of cash flow does not always reinvest their money in unprofitable project. The management might raise more concern on dividend distribution to shareholders or investing the cash to expand the firm or buy new assets.

\section{Conclusion}

One of major problem may be faced by every company is agency problem. According to Jensen and Meckling (1986), agency problem happens when both management and principal are in their own interest to maximise their own wealth. Thus, there is a reason not to believe that management always act on behalf of the shareholders. Jensen suggest that dividend distribution is one of the most often meet agency problem in a company since by 
distributing the dividend, the available resource in cash of a firm is decreasing, and while managers would like to maintain their position and power in a company, instead of paying dividend, they try to invest the available resource in negative present value project by promising the shareholders higher return in the future.

However, keeping the promise of giving higher return to investors is not that easy when manager invest in unpromising investment. Therefore, in order to camouflage the impact of negative investment, earnings management plays role to allow manager having discretion over accruals to present better financial report to the investors. In this study, the researcher would like to investigate whether firm with high free cash flow and low growth perspective are more often engage in earnings management behaviour along with several control variables included to enrich the research.

Our results show that there is no significant influence between higher level of free cash flow and low growth perspective to earnings management. However, we found a positive relationship between free cash flow and discretionary accruals by means of earnings management as other previous researches did. A positive relationship tells us that the higher level of free cash flow, the higher possibility of a firm to engage in earnings management. In Indonesia, we found it to be insignificant eventhough a positive relationship is shown. Possible explanation might be a different type of agency problem, dividend policy and organisation culture a cross-country.

In addition, several control variables such as SIZE, IFRS and AQ (Audit Quality) are found to be significant. Means that these three control variables have significant influence to discretionary accruals by means of earnings management. 


\section{References}

Ardison, K.M.M., Martinez, A.1., Galdi, FC. (2012), "The effect of leverage on earnings management in Brazil", Journal of Scientific and Appiled Accounting, Vol 5, No. 3, pp. 305-324.

Bae, S.C., Chang, K., and Kang, E. (2012), "Culture, corporate governance, and dividend policy: international evidence", Journal of Finance Research, Vol 35, pp. 298-316.

Balachandran, M. (2015, April 9). The Satyam scandal: How India's biggest corporate fraud unfolded. India.

Bukit, R.Br. and Iskandar, J.M. (2009), "Surplus free cash flow, earnings management and audit committee", International Journal of Economics and Management, Vol. 3 No.

1, pp. 204-223.

Baker, H.K. and Powell, G.E. (2012), "Dividend policy in Indonesia: survey evidence from executives", Journal of Asia Business Studies, Vol 6 No.1, pp. 79-92

Bhundia, A. (2012). A comparative study between free cash flow and earnings management.

Nikhili, M., Amar, I. F., Chtioui, T., \& Lakhal, F. (2016). Free cash flow and earnings management: the moderating role of governance and ownership. The Journal of Applied Business Research, 32.

Breurer, W., Rieger, O., \& Soypak, C. (2014). The behavioral foundations of corporate dividend policy: a cross-country analysis (Vol. 42). Elsevier.

Bukit, Rina. and Nasution, Fahmi N. (2015), "Employee diff, free cash flow, corporate governance, and earnings management”, Journal of Social and Behavioral Sciences, Vol. 211, pp. 585-594.

Cardoso, F. T., Martinez, A. L., \& Teixeira, A. J. (2014). Free Cash Flow and Earnings Managemetn in Brazil: The negative side of financial slack. Global Journal of Management and Business Research: Accounting and Auditing, 14.

Bukit, R. B., \& Iskandar, T. M. (2009). surplus free cash flow, earnings managemement, and audit committee. International Journal of Economics and Management .

Chee, H.K., Phua, L.K., Yau, D.L.I. (2016), "The relationship between audit quality, board of independence and audit committee independence on earnings management before and after full convergence of IFRS", Journal of Social Science, Vol. 11 No. 20, pp. 49024906.

Chung, R., Firth, M., \& Kim, J.-B. (2005). Earnings management, surplus free cash flow, and external monitoring. Journal of Business Research , 58, 766-776.

Cornett, M.M., Marcus, A.J., Tehranian, H. (2008), "Corporate governance and pay-forperformance: The impact of earnings management", Journal of Financial Economics, Vol. 87, pp.357-373. 
Dechow, P.M., Sloan, R.G. and Sweeney, A.P. (1995), "Detecting earnings management", The Accounting Review, Vol. 70 No. 2, pp. 193-225.

Dechow, P. M. (1994). Accounting Earnings and Cash Flows as Measures of Firm Performance: The Role of Accounting Accruals. Journal of Accounting \& Economics $18,3-42$.

Francis, J., Nanda, D., \& Olsson, P. (2008). Volentary disclosure, earning quality and cost of capital. Journal of accounting research , 46 no 1, 53-99.

Ghozali, I. (2013). Aplikasi Analisis Multivariate dengan program SPSS. Semarang, Central Java, Indonesia: Universitas Diponegoro.

Gorganlidavaji, J., \& Vakilifard, H. (2014). The Effect of Firm Size and Growth Opportunity on Accounting Discretion and Its Relationship with Future Stock Return. European Online Journal of Natural and Social Sciences , 3 , 511-521.

Hair J. F., Black, W.C., Babin, Barry J., Anderson, R.E. (2009). Multivariate Data Analysis. Prentice Hall.

Healy, P.M. and Palepu, K.G. (1990), "Effectiveness of accounting-based dividend covenants", Journal of Accounting and Economics, Vol. 12 Nos 1/3, pp. 97-123.

Healy, P. M., \& Wahlen, J. M. (1999). A review of the earnings management literature and its implications for standard setting. Accounting Horizons , 13 No 4, 365-383.

Healy, P. M. (1985), The Effect of Bonus Schemes on Accounting Decisions, Journal of Accounting and Economics, vol. 7, no.3, page 85-107;

Jensen, M.C. (1986), "Agency costs of free cash flow, corporate finance and takeovers", American Economics Review, Vol. 76 No. 2, pp. 323-329.

Jeanjean, T., \& Stolowy, H. (2008). Do accounting standards matter? An exploratory analysis of earnings management before and after IFRS adoption. Journal of account.public policy, 27, 480-494.

Jiraporn, P., Kim, Y., \& Mathur, I. (2008). Does Corporate Diversification Exacerbate or Mitigate Earnings Managament?: An empirical analysis. International review of financial analysis , 17 no 5, 1087-1109.

Kim, Y., Liu, C., \& Rhee, S. (2003). The Effect of Firm Size on Earnings Management. University of Hawai'i, College of Business Administration.

Kouki, M., Elkhaldi, A., Atri, H., \& Souid, S. (2011). Does Corporate Governance Constrain Earnings Management? Evidence from US Firms.

European Journal of Economics, Finance and Administrative Sciences , 35.

Krishnan, G. (2003). Does big 6 auditor industry expertise constrain earnings management? Accounting Horizons , 17, 1-16. 
Lin, J. W., \& Hwang, M. I. (2010). Audit quality, corporate governance, and earnings management: A meta-analysis. International Journal of Auditing , 14, 57-77.

Lusi, D., Swastika, T. (2013). Corporate Governance, Firm Size, and Earning Management: Evidence in Indonesia Stock Exchange. Journal of Business and Management. Vo. 10(4), 77- 82.

Nikhili, M., Amar, I. F., Chtioui, T., \& Lakhal, F. (2016). Free cash flow and earnings management: the moderating role of governance and ownership. The Journal of Applied Business Research, 32.

Roychowdhury, S. (2006). Earnings Management through real activities manipulation. Journal of Accounting and Economics , 42, 335-370.

Rusmin Rusmin Emita W. Astami Bambang Hartadi , (2014),"The impact of surplus free c ash flow and audit quality on earnings management", Asian Review of Accounting, Vol. 22 Iss 3 pp. $217-232$.

Sarwono, J. (2016). Prosedur-prosedur analisis populer aplikasi riset skripsi dan tesis dengan Eviews. Gava Media.

Selahudin, N.F., Zakaria, N.B., Sanusi, Z.M. and Budsaratragoon, P. (2014), "Monitoring financial risk ratios and earnings management: evidence from Malaysia and

Thailand", $\quad$ Procedia-Social and Behavioral Sciences, Vol. 14, pp. 51-60.

S.Soderstrom, N., \& Sun, K. J. (2007). IFRS Adoption and Accounting Quality: A Review. European Accounting Review , 16, 675-702.

Sidney Davidson, J. S. (1987). Accounting Magic. In J. S. Sidney Davidson, Accounting: The Language of Business (10th Edition ed.). Sun Lakes Arizona: Thomas Horton and Daughter.

Ujah, N. U., \& Brusa., J. (2014). Earnings Management, Financial Leverage, and Cash Flow Volatilation: An analysis by Industry. Journal of Business and Economics , 5 No 3, 338-348.

Wang, Y. S., \& Huang, P. C. Earnings Manipulation and Profitability. University of Science and Technology, Taiwan, Department of Money and Banking, National Kaohsiung First, Taiwan.

Watts, R.L. and Zimmerman, J.L. (1986), Positive Accounting Theory, Prentice-Hall Inc., Englewood Cliffs, NJ.

Watts, R. L., \& Zimmerman, J. L. (1990). Positive Accounting Theory: A Ten Year Perspective. The Accounting Review , 65, 131-156.

Widyaningdyah, A. U. (2001). Analisis faktor-faktor yang berpengaruh terhadap earnings management pada perusahaan go public di Indonesia. Jurnal Akuntansi \& Keuangan , $3,89-101$. 